\title{
Looking forward to "Working together"
}

Today, I mark my first day as the $9^{\text {th }}$ Editor of IJOEM. I am excited as well as nervous to have caught on the opportunity to take IJOEM to new heights. I am excited because it is matter of great honor to be the Editor of IJOEM and nervous because my predecessors Dr. Rajgopal and Dr. Ramnik Parekh have set such high standard, it seems difficult even to hang on to that level of performance. The earlier Editors Col. Najib Khan, Dr. K. S. Basu, Dr. P. K. Ghosh, Dr. B. B. Chaterjee, Dr. B. Bhar and Dr. B. Banerjee, Our stalwarts did commending job in difficult times and built a strong foundation. It is easy to inherit the proud legacy built by Dr. T. Rajgopal and Dr. Ramnik Parekh in the last 8 years but extremely challenging to deliver that level of performance. I like to thank them for their uncountable and outstanding contributions and commitment to bring IJOEM on international horizon. Together, we can look forward to sustain the success we have achieved and face the inevitable newer challenges. I am a firm believer that the way to achieve success and to pull through the rough patches is personal commitment combined with solid teamwork. I believe "Nobody's perfect, but a team can be." Simply put, everyone counts and I'm counting on you all friends! Looking to the future, we will continue our efforts on innovation, strengthening of financial status, institutional subscriptions and international networking.

I welcome newly appointed editorial team, Advisory board members and Journal committee members and solicit their more than hundred percent support to this scientific activity.

Now that we have journal on web, Please do visit www.ijoem.com our website for online submission of articles and articles of previous issues and new information that you might find useful. We must adopt credible and collaborative approach in realizing our objectives. I end by quoting Henry Ford "Coming together is a beginning, staying together is progress, and working together is success".

Together, let us do it.

G. K. Kulkarni Editor - IJOEM 